\title{
QUANTITATIVE ANALYSIS OF GLACIERS CHANGES FROM PASSAGE CANAL BASED ON GIS AND SATELLITE IMAGES, SOUTH ALASKA
}

\author{
NISTOR, M. M.*1 - PETCU, M. I. ${ }^{2}$ \\ ${ }^{1}$ University of Modena and Reggio Emilia - Department of Chemical and Geological Sciences, \\ S. Eufemia Street, No. 19, 41121, renddel@yahoo.com, Modena, Italy \\ (phone: +39-334-270-7932; fax: +39-059-205-5887) \\ ${ }^{2}$ University of Babeş-Bolyai - Faculty of Geography, Clinicilor Street, No. 5-7, Cluj-Napoca, \\ 400006, , madalin_petcu@yahoo.com, Romania (phone: +40-752-836-905) \\ *Corresponding author \\ e-mail: renddel@yahoo.com \\ (Received $5^{\text {th }}$ Nov 2014; accepted $12^{\text {th }}$ Dec 2014)
}

\begin{abstract}
The physical aspects of three glaciers from Passage Canal have been identified by field research, satellite images, and Geographic Information System. The main objective of this study is to determine the melting area and to calculate the withdrawal rate of Billings, Learnard, and Whittier glaciers. The satellite images from Landsat sensors (1985, 1994, 1999, 2006, 2011, and 2013) helped us to remote sensing observations. To assess the retreat of glaciers, new layers with glaciers' limits reasoning on sixth time-comparable satellite images were created and used for quantitative analysis. The results show that the area of glaciers from Passage Canal was reduced during 1985-2013: Billings Glacier decreased by $2.334 \mathrm{~km}^{2}$, Learnard Glacier decreased by $0.726 \mathrm{~km}^{2}$ and, Whittier Glacier decreased by $1.836 \mathrm{~km}^{2}$. Spatial Analyst Tools was used to determinate the Euclidean Distance of Billings Glacier, Learnard, and Whittier glaciers to Passage Canal. The first set of results obtained indicates that movement of glaciers is active and retired. An average ratio of melting area were determined for the period from 1985 to 2013: Billings Glacier was $0.08 \mathrm{~km}^{2} /$ year, Learnard Glacier was $0.02 \mathrm{~km}^{2} /$ year, and Whittier Glacier was $0.06 \mathrm{~km}^{2} / \mathrm{year}$. These results indicates that retreat of glaciers is slow, but constant.

Keywords: glaciers, satellite images, GIS, climate change, Passage Canal.
\end{abstract}

$\begin{array}{ll}\text { Abbreviations } \\ \text { GL(s) } & \text { Glacier(s) } \\ \text { SI(s) } & \text { Satellite image(s) } \\ \text { GIS } & \text { Geographic Information System } \\ \text { SAT } & \text { Spatial Analyst Tools } \\ \text { SST } & \text { Spatial Statistics Tools } \\ \text { PC } & \text { Passage Canal } \\ \text { ED } & \text { Euclidean Distance } \\ \text { SST } & \text { Spatial Statistics Tools } \\ \text { CM } & \text { Central Mean } \\ \text { TM } & \text { Thematic Mapper } \\ \text { ETM+ } & \text { Enhanced Thematic Mapper Plus } \\ \text { MODIS } & \text { Moderate-Resolution Imaging Spectroradiometer } \\ \text { AVHRR } & \text { Advanced Very High Resolution Radiometer } \\ \text { EROS } & \text { Earth Resources Observation Satellite and } \\ \text { ASTER } & \text { Advanced Spaceborne Thermal Emission and Reflection Radiometer } \\ \text { SAR } & \text { Synthetic Aperture Radar } \\ \text { SPOT } & \text { Satellite for Observation of Earth } \\ \text { DEM } & \text { Digital Elevation Model } \\ \text { GPS } & \text { Global Positioning System } \\ \text { asl } & \text { above sea level }\end{array}$




\section{Introduction}

Climate change has become a central issue in glaciers (GLs) melting. In Passage Canal (PC) from Prince William Sound, a rise in temperature with $2-3{ }^{\circ}$ Celsius and a reduction of precipitation with $10 \%$ is predicted for the next 50 years (Stavig et al., 2005). According to Molnia (2006), after the Little Ice Age not all GLs from Alaska demonstrated behaviors related to climate change, some of them registered movements due to surge dynamics. The end of Little Ice Age and increasing industrial black carbon are considered the factors that affected the GLs retreat in Europe during the $20^{\text {th }}$ century (Painter et al., 2013) and worldwide there is a complex relationship between climate and GLs (Oerlemans, 1994; Haeberli et al., 1998).

Surface displacement and ice mass fluctuation were demonstrated by GLs from South Alaska related to earthquakes and active tectonics (Sauber and Molnia, 2003). The landslides and thick debris cover triggered by earthquakes can significantly change the ablation rate of GLs (Post, 1967; Krimmel and Meier, 1989). Fountain and Walder (1998) highlighted that water inside GLs affects movements profoundly because of "stress distribution at the glacier bed".

We chose to study Billings GL, Learnard GL and Whittier GL from this zone of the world for many reasons: first, because in the last three decade these GLs have not signaled significant changes and thus, we wanted to check if they are stabilized or not. Secondly, as the local climate is influenced by Chugach Mountains north of PC and Kenai Mountains south of PC, these GLs have different comportment. Thirdly, PC represent a considerable pole of salmon fisheries of the world. Daily, 600,000 - 750,000 pounds of salmon have passed for processing only in one factory. Climate warming and GLs melting implies the changes in terrestrial and marine ecosystems. Considering that South Alaska are the largest exporter of salmon from entire world, is vital to study the GLs and evolution of environment. We will present how evolve the changes at Billings GL, Learnard GL and Whittier GL in the period mentioned above.

Remote Sensing with satellite images (SIs) and Geographic Information System (GIS) applications have been widely applied to the study of the Billings, Learnard and Whittier GLs retreat; in particular with regard to the terminus movements and decrease in size during 1985-2013. Increasing global climate has affected many GLs (Oerlemans, 2005). The GLs are the most sensitive indicators of climate change (Haeberli et al., 1999; Kargel et al., 2005; Dong et al., 2013), which give a glacierized face at alpine landscape (O'Neel et al., 2014). As a result of climate warming, the GLs have continuously declined at many sites on the Globe (Shahgedanova et al., 2005; Kennedy et al., 2006; Painter et al., 2013).

To the best of our knowledge, there are no published research findings regarding lose area value for Billings GL, Learnard GL and Whittier GL in the last fifty years. This article proposes a quantitative analysis based on remote sensing with SIs and GIS for assessment of the retreat terminus and area of GLs from PC under recent climate change. The aim of the present work is to calculate the rate of retreat of Billings GL, Learnard GL and Whittier GL.

Previous researches tend to focus on length and square area of GLs rather than volume. The expected outcome offer real data about status of these GLs. Quantitative analysis of length and area were obtained with remote sensing and GIS Software from ESRI. SIs and GIS allowed us to do spatial analysis, calculate square area and CM of each GL. Due to its capacity in spatial analysis, raster integration and mathematical 
functions, GIS has become, with remote sensing, a method for Earth's survey (Brown et al., 2005; Jha et al., 2008; Hadeel et al., 2010; Erdős et al., 2013; Elfarrak et al., 2014; Sambah et al., 2014). The potential of remote sensing for GLs exploration has been demonstrated by Willis et al. (2011), Dong et al. (2013). Qinghua et al. (2006) using appropriate methods based on GIS and remote sensing for quantitative measurements in area at the GL present in Geladandong mountain region, during 1973-2002.

Paul et al. (2002) developed an inventory about methods of classification of Swiss GL. In their study, Landsat Thematic Mapper (TM) and GIS were used from the point of view of computation of GL parameters. Various SIs, such as Moderate-Resolution Imaging Spectroradiometer (MODIS), Advanced Very High Resolution Radiometer (AVHRR), Earth Resources Observation Satellite (EROS) and Advanced Spaceborne Thermal Emission and Reflection Radiometer (ASTER), were adopted for investigating the geospatial resources and data regarding Alaska (Wirth et al. 2014). It has been claimed by Molnia (2001) that Landsat images, ground and aerial observation supply an excellent source of data on area extension and changes in the GLs of Alaska. Ommanney (2002) used Landsat images and aerial photographs for GLs observations from Rocky Mountains, Canada. Synthetic Aperture Radar (SAR) and Satellite for Observation of Earth (SPOT) images were analyzed for describing GLs of the Arctic Islands by Jeffries (2002).

Zhang et al. (2000) found that area underlain by permafrost in Northern Hemisphere is $12 \%$ to $18 \%$. The general tendency is that the GLs from PC are retreating, but the ration of melting area for set interval periods is not checked until now. Research show few examples about status of PC's GLs. Between 1994 and 2001, 11 GLs were profiled in the Chugach Mountains, 13 GLs in the Kenai Mountains and other GLs in Alaska Range, Saint Elias Mountains and Coast Mountains (Echelmeyer et al., 2004). A study of the level of snow-cover presence in North America, made comparing MODIS with Defense Meteorological Satellite Program is presented by Hall et al. (2002).

Our study provides additional support for knowledge on Billings GL, Learnard GL and Whittier GL.

This paper is divided into five sections. The first section gives a brief overview of objectives and current studies about GLs and climate change. In the second section a case study is present and outlines our methods for making quantitative analysis. In Section 3 the results of the research show a reducing of ice mass at GLs from PC, from 1985 to present and discusses the GLs case studies regarding at identifiable parameters. Our conclusions are drawn in the final section.

\section{Materials and methods}

\section{Study area}

The study area includes the west of Chugach Ranges and north of Kenai Ranges and extends between $60^{\circ} 43^{\prime}-60^{\circ} 55^{\prime} \mathrm{N}$ and $148^{\circ} 25^{\prime}-148^{\circ} 44^{\prime} \mathrm{W}$ (Figure 1). PC is situated west of Prince William Sound and represent a fjord bounded north by Chughach Mountains and south by Kenai Mountains. In PC there are many type of mountains GLs presented: tidewater GLs, valley GLs, outlet GLs and hanging GLs. Kachadoorian (1965) has noted that the climate of this area is intermediate between coastal mountains and open coast. From 1965 until now, the climate change was pronounced and, currently, it is possible that most GLs from PC change their response at climate change, including the snow disappearance (Mefford and Dutton, 2003). The retreat of Portage 
GL, situated west of Whittier, has been demonstrated by Mayo et al. (1977), Kennedy et al. (2006). Physical characteristics of test GLs in 2013 are highlighted in Table 1.

Table 1. Assessment of physical characteristics of inventoried glaciers in 2013.

\begin{tabular}{cccccc}
\hline Glacier & $\begin{array}{c}\text { Length } \\
(\mathrm{km})\end{array}$ & Square area $\left(\mathrm{km}^{2}\right)$ & $\begin{array}{c}\text { Top elevation } \\
(\mathrm{m})\end{array}$ & $\begin{array}{c}\text { Bottom elevation } \\
(\mathrm{m})\end{array}$ & Direction of flow \\
\hline Billings & 7.49 & 9.568 & 1589 & 284 & NE-SW, N-S \\
Learnard & 4.15 & 3.113 & 1341 & 352 & N-S \\
Whittier & 4.33 & 6.724 & 1013 & 470 & SSW-NNE \\
\hline
\end{tabular}

Source: GIS statistics

Billings GL is characterized like a valley GL (Figure 2A) and is approximately 7.49 $\mathrm{km}$ long. It is situated north of PC and is approximately $9.568 \mathrm{~km}^{2}$ in area. The Billings GL runs altitudinal $284 \mathrm{~m}$ above sea level (asl) and $1589 \mathrm{~m}$ asl and has a flow direction of $\mathrm{NE}$ to $\mathrm{SW}$ and $\mathrm{N}$ to $\mathrm{S}$. The moraines ridges and the moraine deposits on slip plane offer information about intensity of activity in the past for Billings GL (Figure 3A). Hoekzema and Sherman (1981) mention that the first investigation on Billings GL was for gold explorations. Hoekzema and Sherman (1981) analyzed the topographic map elaborated by the United States Geological Survey from 1951 and aerial photos from the United States Forest Service 1974. Later, they reported that "the GL retreated rapidly since 1950".

Learnard GL is a valley GL (Fig. 2B) and is $4.15 \mathrm{~km}$ in length and occupies 3.113

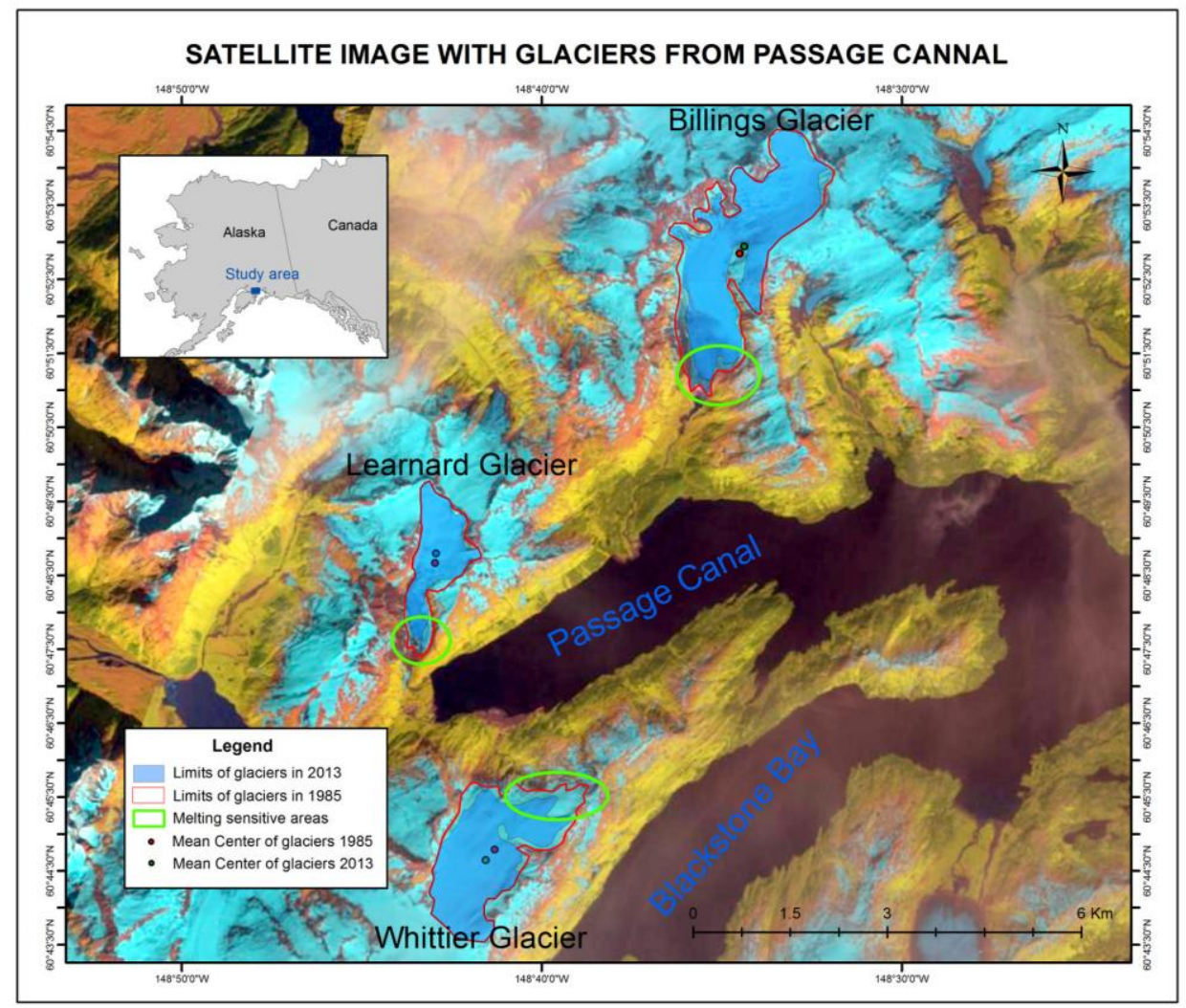

Figure 1. Landsat 4 Enhanced Thematic Mapper Plus (ETM+) mosaic image depicting the study area in 1985. Landsat images courtesy of the U.S. Geological Survey. 
$\mathrm{km}^{2}$ of area. Learnard GL is positioned in the head of fjord, on Northwest flank and has $\mathrm{N}$ to $\mathrm{S}$ orientation. At terminus, Learnard GL ends in a narrow valley (Figure $3 B$ ) with rocks fall and erratics boulders (Nistor, 2013). In 1943 the terminus of Learnard GL ended about 200 feet asl, which representing $60 \mathrm{~m}$ asl (Barnes, 1943). Unfortunately, the total area of Learnard GL was not known at the time (Barnes, 1943).
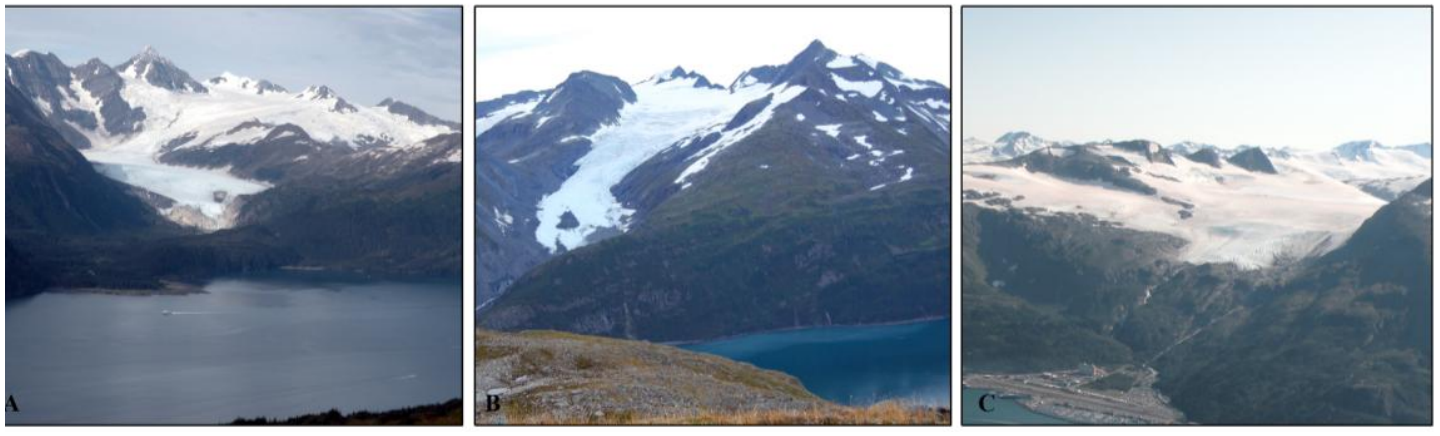

Figure 2. Three views of test glaciers. A. Autumn 2009 northeast-looking oblique aerial photograph of Billings Glacier. B. Autumn 2010 north-looking ground photograph of Learnard Glacier. C. Autumn 2009 oblique south-looking aerial photograph of Whittier Glacier. Photo courtesy: Nistor.

Whittier GL is located south of PC and is $4.33 \mathrm{~km}$ long. This is an outlet GL (Figure $2 C$ ) and has portions with different rate of retreat. The flow direction is SSW to NNE. In ablation zone of Whittier GL sheepback landforms and glacial striations can be visible (Figure 3C). Krimmel and Meier (1989) bring to the forefront the oldest data about Whittier GL available and mention that in 1910 the terminus of Whittier was one $\mathrm{km}$ from PC. As mentioned by Barnes (1943), Molnia (2008) reported that, between 1913 and 1939, terminus of Whittier GL had retreated "several hundred feet" and the elevation of terminus was modified from $180 \mathrm{~m}$ asl level to $300 \mathrm{~m}$ asl. The creek that proceeds Whittier GL formed a wonderful delta (Kachadoorian, 1965), where Whittier town is constructed.
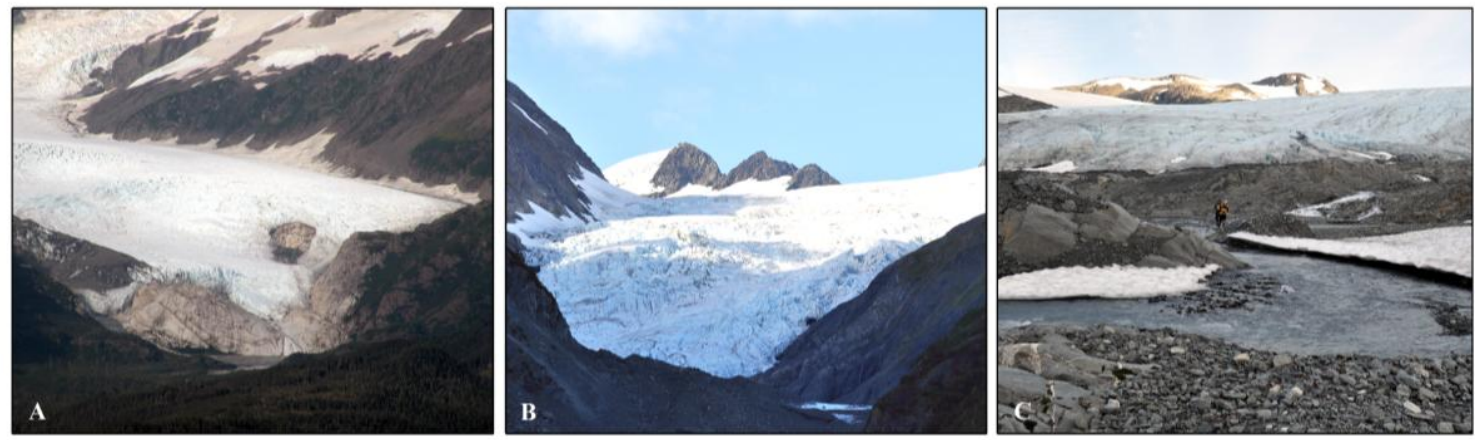

Figure 3. A. Autumn 2009, aerial photograph of Billings Glacier terminus. B. Summer 2010, ground photograph of Learnard Glacier. C. Autumn 2010, ground photograph of Whittier Glacier terminus. Photo courtesy: Petcu. 


\section{Overview of the approach}

The main objective of this research was to evaluate the area of GLs in several stages and to indicate the sectors of the maximum melting in the ice mass. The procedures used to determinate the extension of GLs is based on SIs and GIS at three GLs from PC, in Whittier area, Alaska. The method described here is simple and enables us to obtain good results at local scale. We chose ArcGIS software because it incorporates a set of applications in Spatial Analyst Tools (SAT) and Spatial Statistics Tools (SST), available for elaborate efficient the data.

In an attempt to identify the square area of GLs, it was decided to use remote sensing because the SIs are easy to integrate in GIS, Holobâcă (2013), for its low cost, for georeferenced images and quality of scenes, displayed on Landsat Look Viewer (United States Geological Survey 2014). Gao and Liu (2001) confirm that the remote sensing is an efficient method of data collection for GLs. To highlight the advantages of work system, Figure 4 shows the overview of the applied methodology.

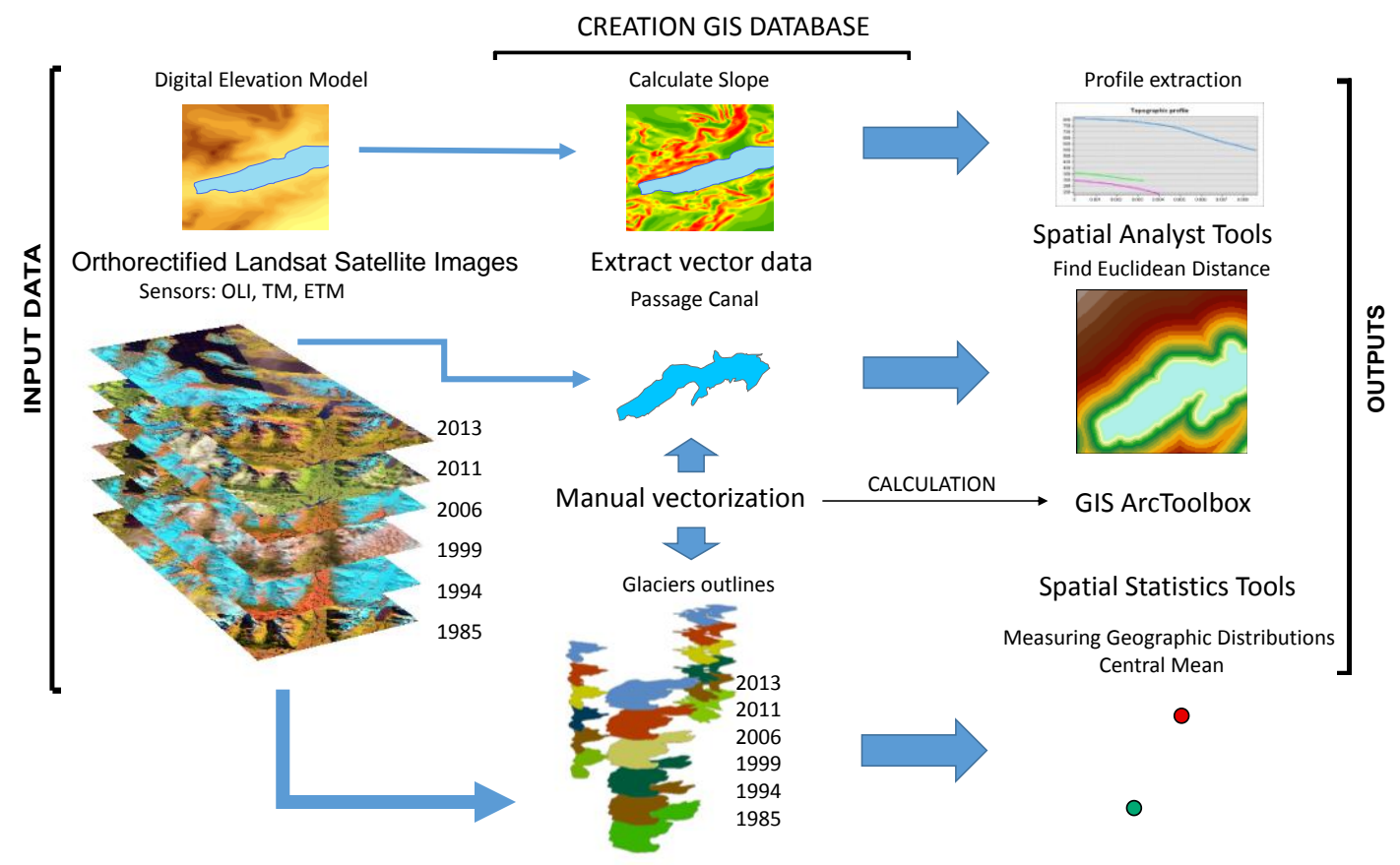

Figure 4. Schematic diagram showing the methodology step.

\section{Remote sensing}

The remote sensing with SIs enabled assessment of the movement of Billings GL, Learnard GL and Whittier GL over the last three decades. The remote sensing was applied only in summer and autumn months, thus the results cannot be influenced by snow. We monitored the positions of GLs using Landsat 4. We analyzed the SIs in spectral visible from 1985, 1994, 1999, 2006, 2011 and 2013, available on United States Geological Survey's Earth Resources Observation web-site (2014).

The terrestrial remote sensing and the field investigations helped us to pinpoint the GLs limits where the Billings GL, Learnard GL and Whittier GL are in contact with 
other GLs. This is essential because with SIs it is more difficult to draw the boundaries of two attached GLs. For field work we used topographic maps at 1:25000 scales, elaborated by the United States Geological Survey National Elevation Dataset. This approach has proven to be important because afterwards we succeeded in selecting the information. For example, we recall the ice extent and aspects of slopes.

\section{GIS geodatabase extraction}

Using the vectorization, we extracted the ecosystem information with all its components: the contour lines, the GLs outlines and PC fjord. Due to a full resolution and minimal cloudiness of SIs, it was possible to realize the limits of the three GL.

We extracted the data from SIs by manual digitizing. The vectorization is more important than processing raster data, because we can calculate with more precision the dimensions of GLs and we diminished the errors that appear in the same time with conversion from one system to another. This procedure is recognized by Raup et al. (2007) as a high accuracy method for extracting outlines of GLs. Vector results of GLs in different years were compared to observe the changes. In some cases, the vector data can be compared with extracted data from expert system (Elshehaby and Taha, 2009).

To estimate area change, we use Landsat 4 images that have been used for obtaining vector data, which show how GLs area differ and can then infer average areas change rates. If the GLs have a small area, the rate will be negative. If the GLs have a major area, the rate will be positive.

\section{Quantitative analysis}

We used SAT from ArcToolbox GIS 10.1 in order to apply Euclidean Distance (ED) and to calculate the slope from Digital Elevation Model (DEM). ED was significant for identification distance of terminus points of Billings GL, Learnard GL and Whittier GL to PC in 1985 and 2013.

The quantitative analysis used involves two steps: i) we applied SAT at PC feature, extracted from SIs to obtain ED of GLs terminus in 1985 and 2013; ii) we applied SST to GLs outlines for centroids found and quantified general movement of GLs.

Using SAT we found an increased distance of the GLs from PC. We applied ED in the vector map of PC to generate coast-line distance (Figure 5).

Slope function work after principle was proposed by Burrough and McDonell (1998).

Using the slope and topographic profile we determined the relationship between length of terminus retreat and differences of terminus altitude. The ED and Slope functions are essentially the same as that used by Sambah and Miura (2014) that measured the coastline distance in their study about tsunami in the East of Japan.

SST from GIS was used to quantify the area sensitive to melting for the studied GLs. Specifically, in our procedure we applied Central Mean (CM) tool, founded in Measuring Geographic Distributions Tools, on GLs outlines for determinating the direction and distance of general retreat. This concept of CM was introduced by Kuhn and Kuenne (1962) and after was delineated by Burt and Barber (1996). We found the centroids of GLs for identifies the tendency for general ice loss using the CM function from SST. The algorithm computes the minimal distance to all features and the result gives the location of the center of the cluster. In our case, CM represents the central point of GLs, in 1985 and 2013. At the same time, CM is responsible for interpreting 
the direction of GLs reducing. Thus, we made the linear difference of centroids features between 1985 and 2013 and we succeeded to determinate which part of GLs is more sensitive to melting. In fact, we found where the major retreat is.

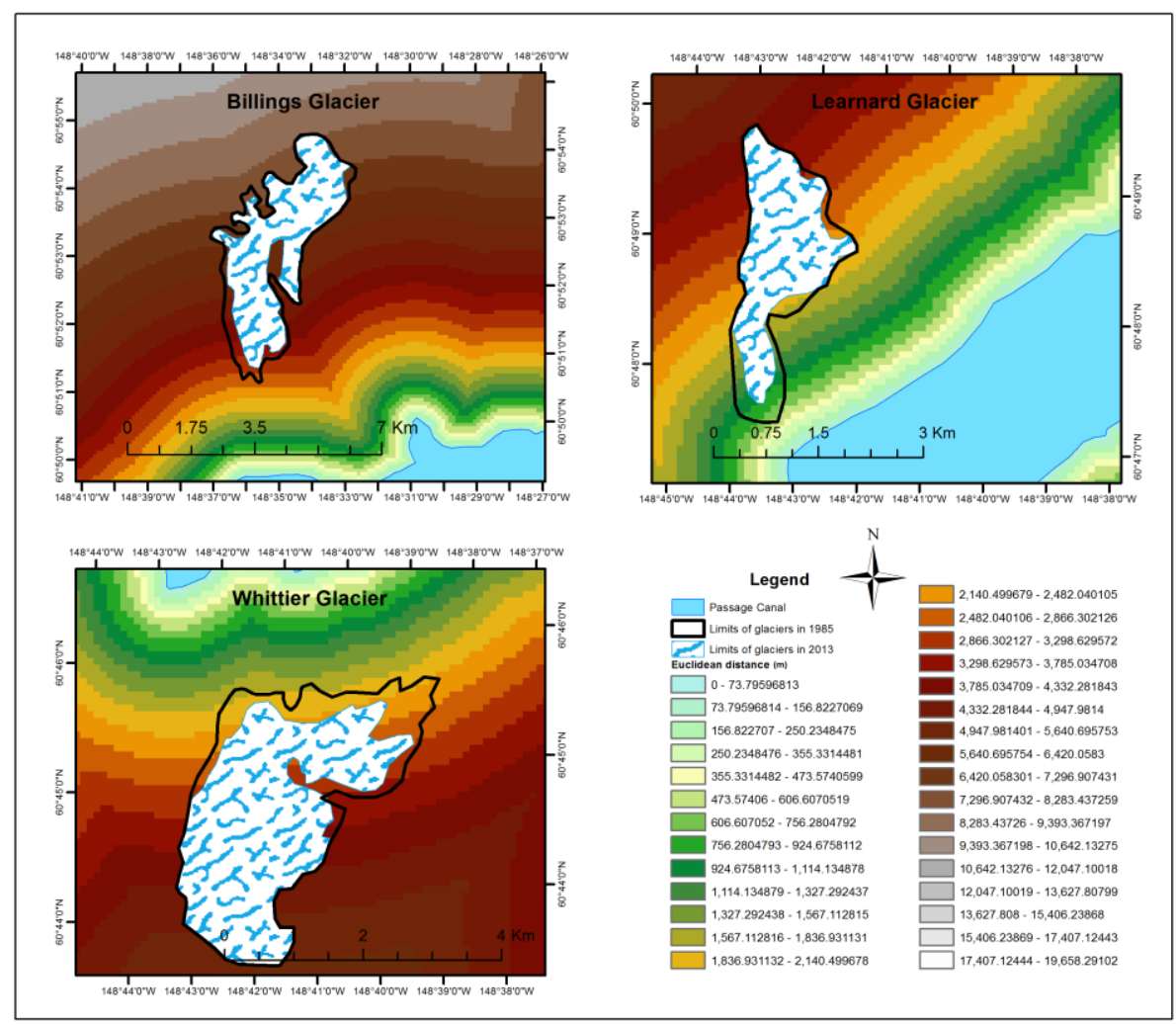

Figure 5. Change outlines of test glaciers based on coastline Euclidean Distance.

\section{Results}

Overall, the results presented below show that the Billings Glacier, Learnard GL and Whittier Glacier have retreated. Changes in covered surfaces by the studied GLs for this article were identified using Sis and GIS. Intersect function from Analysis Tools was used to confirm the difference of GLs outlines during 1985-2013.

Based on vector data (Figure 6) extracted from Landsat images we calculated the total area in square $\mathrm{km}$. To assess the retreat of each GL the difference between initial position and present day position of terminus was distinguished. We observed that extensions of GLs was differ in the six ranges of periods. Table 2 reports the area of Billings GL, Learnard GL and Whittier GL, in the set time intervals.

The most striking movement to emerge from the data is that the Whittier GL recorded considerable differences at terminus between East and West. Whittier GL has a maximum withdrawal in its Eastern part, $964.51 \mathrm{~m}$ and, has a minimum withdrawal in its Western part, $241.1 \mathrm{~m}$ in period 1985-2013. We have found an average withdrawal of $562.3 \mathrm{~m}$, on the center of slip plane of GL at terminus. The area of Whittier GL was diminished by $1.836 \mathrm{~km}^{2}$.

Changes in area and length were identified using ED at Billings GL. Between 1985 to 2013 , Billings GL recorded a $400.76 \mathrm{~m}$ of retreat and a decrease of $2.334 \mathrm{~km}^{2}$. 
No significant differences were found at Learnard GL. This analysis showed that Learnard GL has the smallest regression during 1985 - 2013, with a recording of 238.16 $\mathrm{m}$ of retreat at terminus and loss of approximately $0.726 \mathrm{~km}^{2}$ in area.

An overview shows that in the first half of the observation period, Billings GL and Whittier GL experienced a greater decrease than in the second period. Between $1985-$ 1999 Billings GL reduced by $1.302 \mathrm{~km}^{2}$ and $1.032 \mathrm{~km}^{2}$ between 1999-2013 while Whittier GL decreased by $1.011 \mathrm{~km}^{2}$ between $1985-1999$ and $0.826 \mathrm{~km}^{2}$ between 1999 2013. Contrastingly, Learnard GL exhibited a decrease of $0.312 \mathrm{~km}^{2}$ between $1985-$ 1999 and, after that a decrease of $0.414 \mathrm{~km}^{2}$.

Comparison of the movements of Billings GL during each monitoring stage indicated that the largest mass of ice melted during the $1994-1999$ period. The area lost was $0.636 \mathrm{~km}^{2}$, with a mean annual withdrawal rate of $0.127 \mathrm{~km}^{2} /$ year. Unexpectedly, for high values of area and length, Learnard GL has the largest area of retreat during 2011 2013, $0.147 \mathrm{~km}^{2}$ and a ratio of $0.074 \mathrm{~km}^{2} /$ year was found. Whittier GL lost its maximum area of retreat between $2011-2013,0.211 \mathrm{~km}^{2}$ and retreat rate of $0.105 \mathrm{~km}^{2}$.

The topographic profiles of slip planes in 1985-2013 indicate that the Billings GL terminus moved up approximately $95.81 \mathrm{~m}$ altitude, the Learnard GL moved up $40.07 \mathrm{~m}$ altitude and Whittier GL terminus moved up approximately $127.75 \mathrm{~m}$ altitude. The values are in strong agreement with the increase in temperature between 1992-1994, 1996-1998 and 2008-2010 (Western Regional Climate Center). Figure 7 represent the topographic profiles of GLs and shows the relationship between the altitude terminus and the length distance, from 1985 to 2013.

It is interesting to note that the CM of Learnard GL moved North with $245.36 \mathrm{~m}$. On the other hand, we found that the regression at terminus was $238.16 \mathrm{~m}$. This value of CM indicates a decrease in width of Learnard GL, in ablation zone. The CM of Whittier GL moved SW with $348.96 \mathrm{~m}$. This value correlates with our results obtained for terminus retreat. Results for CM at Billings GL were as expected. CM of Billings GL was positioned in 2013 with a difference of $216.98 \mathrm{~m}$ to NE, compared with 1985.

These results appear to show the influence of an ocean surrounding the GLs. Although this is a small study, the methods can be applied for others GLs. Our findings regarding $\mathrm{CM}$ suggest that:

- Billings GL is more sensitive in southern part;

- Learnard GL is more sensitive in southern, eastern and western part of ablation zone;

- Whittier GL is more sensitive in north-eastern part.

Table 2. Area reduction for glaciers during 1985-2013.

\begin{tabular}{cccc}
\hline Year & $\begin{array}{c}\text { Billings Glacier area } \\
\left(\mathrm{km}^{2}\right)\end{array}$ & $\begin{array}{c}\text { Leamard Glacier area } \\
\left(\mathrm{km}^{2}\right)\end{array}$ & $\begin{array}{c}\text { Whittier Glacier area } \\
\left(\mathrm{km}^{2}\right)\end{array}$ \\
\hline 1985 & 11.902 & 3.839 & 8.560 \\
1994 & 11.236 & 3.668 & 8.008 \\
1999 & 10.600 & 3.527 & 7.550 \\
2006 & 10.127 & 3.410 & 7.279 \\
2011 & 9.661 & 3.260 & 6.935 \\
2013 & 9.568 & 3.113 & 6.724 \\
\hline $1985-2013$ & 2.334 & 0.726 & 1.836
\end{tabular}



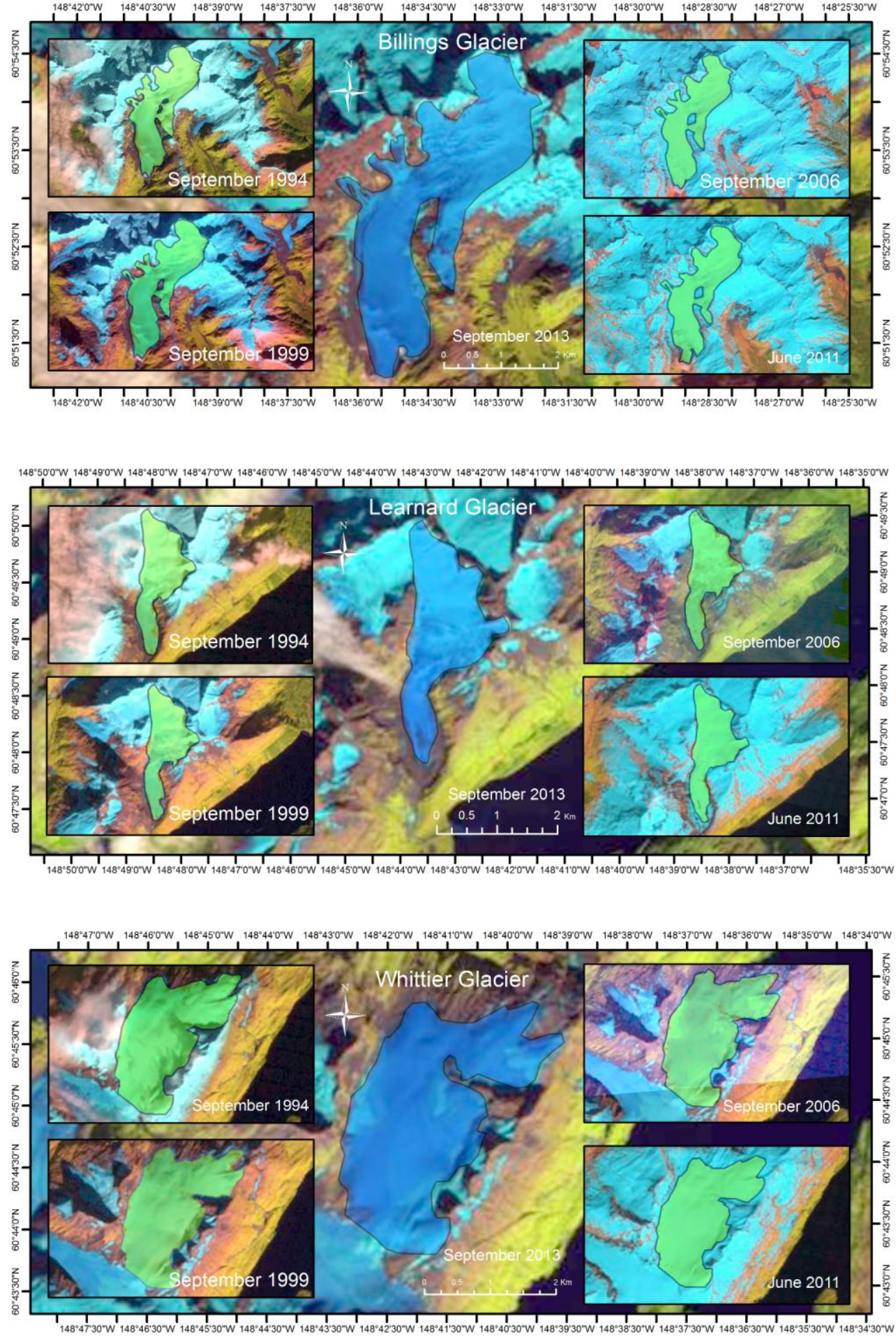

Figure 6. Landsat 4 full resolution mosaic images of Billings Glacier, Learnard Glacier and Whittier Glacier outlines in 1994, 1999, 2006, 2011 and 2013. Landsat images courtesy of the U.S. Geological Survey. 

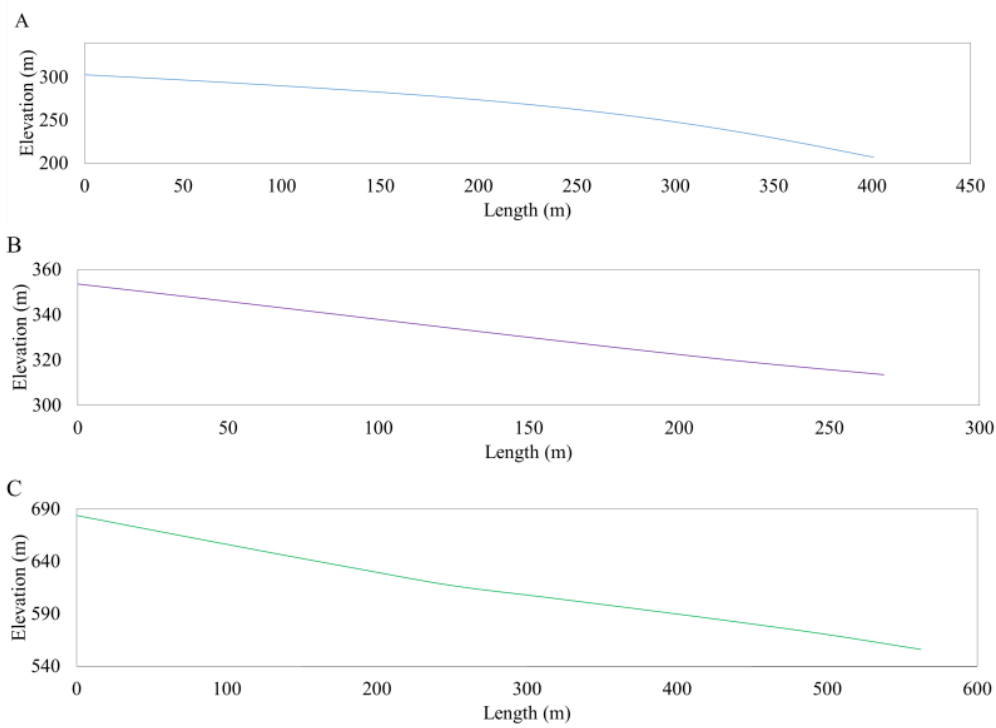

Figure 7. Topographic profiles of slip plane between 1985-2013. A. Billings Glacier. B. Learnard Glacier. C. Whittier Glacier.
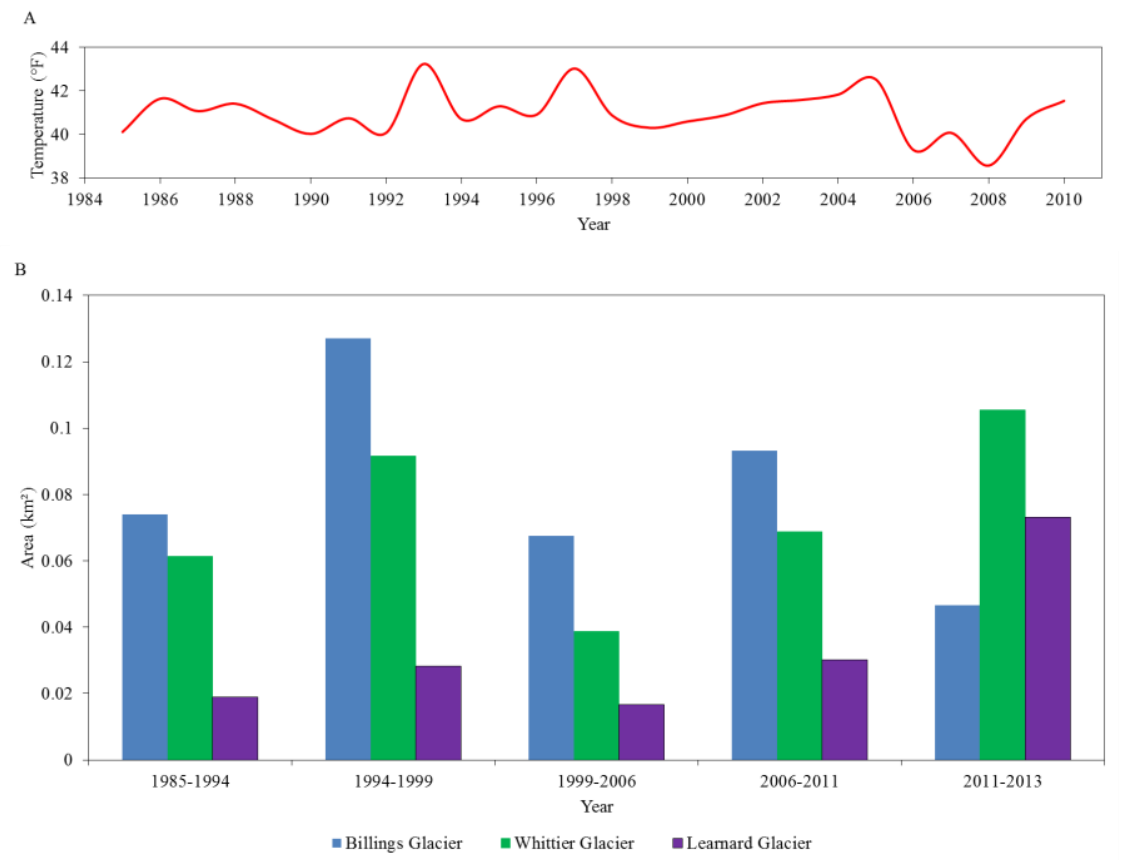

Figure 8. A. Deviation of annual temperature from the 1985-2010, Source: Western Regional Climate Center. B. The withdrawal ratio of GLs in the set time intervals.

\section{Discussion}

One of the main goals of this study was to quantify the retreat of GLs from PC. Looking at results, we expected to obtain the largest area decreasing in the last 5 years. The melting periods of GLs had the highest ratio during 1994-1999 and 2011-2013 (Figure 8). We did not expect that in 1985-1999 the melting area of ice mass to be almost equal compared with ice mass melting during 1999-2013. The retreat of all three 
GLs in the same period, without earthquakes and landslides (Sauber and Molnia, 2003), help us understand that the main factor contributing to the melting is climate change (Oerlemans, 1994; Haeberli et al., 1998).

The retreat of Learnard GL and Billings GL cannot have a negative impact for human establishment. In the case of Whittier GL retreat, it is likely to happen floods of Whittier town and a greater quantity of sediments transported by Whittier Creek can block the harbor activity. In the same time, the retreat of GLs increased sea level and decreased shorelines (Khalsa et al., 2004), affecting the coastline ecosystems. Nistor and Petcu (in press), in theirs paper about Prince William Sound, explains how could be evolve the landscape ecosystems under GLs retreat. They remind three possibilities of developing a new ecosystem: shrubs and after forest ecosystem, lake or fiord with marine ecosystem. Near the coast, the GLs melting affects the fresh waters ecosystems and salmon prohibition (Stavig et al., 2005). Globally, Larsen et al. (2007) notes that the GLs melting contributed to past century rises of sea level.

One limitation of our research was the 2D size. Clearly length and area are not enough to make generalizations about the volume of GLs. However, from the results of those limited number of tendency, a clear pattern emerged which can be useful for actual century scenarios. So, using our method, we didn't calculate the volume of ice loss by each GL, but this does not affect our results in terms of quantitative analysis.

A full treatment of our monitoring using remote sensing and GIS is a complicated operation, in our case, given the hardly accessible area. The measurement made by Global Positioning System (GPS) was not included in our monitoring. In fact, we cannot check the movements in different transversal sections of GLs. Moreover, the continuous monitoring points with GPS are not well suited to describing the change in area. At the same time, the properties of measurement points with GPS reflect the movements of ice mass in particular locations, but not the general tendency. The possibility of monitoring the GLs to observe changes by analysis using SIs and GIS is an exciting proposition.

\section{Conclusions}

Our research has underlined the importance of SIs and GIS for determinating GLs outlines changes. In PC, the GLs's areas and retreat rate have been calculated for the last three decades as influence of recent climate change. The applied methodology allowed us to generate the quantitative analysis. We strongly believe that our method could be applied reliably in other glaciology context without a significant degradation in performance. The results of this study indicate that Billings GL, Learnard GL and Whittier GL are continuously in retreat. Temperature's trend and the images observed during the last three decades confirmed that climate change marks the Southern Alaska. We have used the SAT and SST to observe the sensitive side of GLs at melting. By applying the CM of each GL in 1985 and 2013, we obtained accurate results showing that the CM moved at each inventoried GL toward accumulation area. Consequently, we observed that the principal retreat is over North-East at Billings GL, North at Learnard GL and South-West at Whittier GL. This signifies that the geographical position and relief are the main factors that influence the way of retreat. Taken together, these findings highlight a role of SAT and SST for analyzing the components of environment at different layers. These findings add to a growing body of research literature on GLs 
from PC and South Alaska, because no work has yet been published on the movements of these GLs - an area in which can contribute to the knowledge of GLs.

It is hoped that the observations from our studies will contribute to hydrology of Whittier, Learnard, and Billings Creeks. In the same time, evolution of landscape and it's implication for ecosystems is important for sustainable developing of respective territory. If possible, future work will focus on radar imagery measurements for understanding GLs dynamics, flow velocity and estimating volume of these GLs.

\section{REFERENCES}

[1] Barnes, F.F. (1943): Geology of the Portage Pass area, Alaska. - United States Geological Survey Bulletin. Government Printing Office Washington 926D: 211-235.

[2] Brown, D.G., Riolo, R., Robinson, D.T., North, M., Rand, W. (2005): Spatial process and data models: Toward integration of agent-based models and GIS. - Journal of Geographical Systems Springer-Verlaag 7: 25-47.

[3] Burrough, P.A, McDonell, R.A. (1998): Principles of geographical information systems. - Oxford University Press. New York.

[4] Burt, J.E., Barber, G. (1996): Elementary statistics for geographers. - Guilford, New York.

[5] Clayton, L., Attig, J.W., Mickelson, D.M., Johnson, M.D. (1991): Glaciation of Wisconsin. - WI: Wisconsin Geological and Natural History Survey.

[6] Dong, P., Wang, C., Ding, J. (2013): Estimating glacier volume loss used remotely sensed images, digital elevation data, and GIS modelling. - International Journal of Remote Sensing 34(24): 8881-8892.

[7] Echelmeyer, K.A., Valentine, V.B., Zirnheld, S.L. (2004): Airborne surface profiling of Alaskan glaciers. - Boulder Colorado USA: National Snow and Ice Data Center.

[8] Elfarrak, H., Hakdaoui, M., Fikri, A. (2014): Development of Vulnerability through the DRASTIC Method and Geographic Information System (GIS) (Case Groundwater of Berrchid), Morocco. - Journal of Geographic Information System 6: 45-58.

[9] Elshehaby, A.R., Taha, L.G.E. (2009): A new expert system module for building detection in urban areas using spectral information and LIDAR data. - Applied Geomatics 1: 97-110.

[10] Erdős, L., Cserhalmi, D., Bátori, Z., Kiss, T., Morschhauser, T., Benyhe, B., Dénes, A. (2013): Shrub encroachment in a wooded-steppe mosaic: Combining GIS methods with landscape historical analysis. - Applied Ecology and Environmental Research 11(3): 371384.

[11] Fountain, A.G., Walder, J.S. (1998): Water flow through temperate glaciers. - American Geophysical Union 36(3): 299-238.

[12] Gao, J., Liu, Y. (2001): Applications of remote sensing, GIS and GPS in glaciology: a review. -Progress in Physical Geography 25 (4): 520-540.

[13] Hadeel, A.S, Jabbar, M.T., Chen, X. (2010): Application of remote sensing and GIS in the study of environmental sensitivity to desertification: a case study in Basrah Province, southern part of Iraq. - Applied Geomatics 2:101-112.

[14] Haeberli, W.R., Frauenfelder, R., Hoelzle, M., Maisch, M. (1999): On rates and acceleration trends of global glacier mass changes. - Physical Geography 81A: 585- 595 .

[15] Haeberli, W., Beniston, M. (1998): Climate change and its impacts on glaciers and permafrost in the Alps. - Ambio 27(4): 258-265.

[16] Hall, D.K., Kelly, R.E.J., Riggs, G.A., Chang, A.T.C., Foster, J.L. (2002): Assessment of the relative accuracy of hemispheric-scale snow-cover maps. - International Glaciological Society 34(1): 24-30. 
[17] Hoekzema, R.B., Sherman, G.E., (1982): Billings Glacier Molybdenum-Copper occurrence. - Anchorage: Field Operations Center.

[18] Holobâcă, I.H. (2013): Glacier Mapper - a new method designed to assess change in mountain glaciers. - International Journal of Remote Sensing 34(23): 8475-8490.

[19] Jha, M.N., Levy, J., Gao, T. (2008): Advances in Remote Sensing for Oil Spill Disaster Management: State-of-the-Art Sensors Technology for Oil Spill Surveillance. - Sensors 8: $236-255$.

[20] Jeffries, M.O. (2002). Glaciers of the Arctic Islands. - United States Geological Survey Proffesional Paper 1386-J. University of Michigan Libraries.

[21] Kachadoorian, R. (1965): Effects of the Earthquake Of March 27,1964 At Whittier, Alaska. -United States Government Printing Office Washington D.C.

[22] Kargel, J.S., Abrams, M.J., Bishop, M.P., Bush, A., Hamilton, G., Jiskoot, H., Kääb, A., Kieffer, H.H., Lee, E.M., Paul, F., Rau, F., Raup, B., Shroder, J.F., Soltesz, D., Stainforth, S., Stearns, L., Wessels, R. (2005): Multispectral imaging contributions to global land ice measurements from space. - Remote Sensing of Environment 99(1): 187219.

[23] Kennedy, B.W., Trabant, D.C., Mayo, L.R. (2006): A century of retreat at Portage Glacier, South-Central Alaska. - Anchorage: United States Geological Survey.

[24] Khalsa, S.J.S., Dyurgerov, M.B., Khromova, T., Raup, B.H., Barry R.G. (2004): SpaceBased Mapping of Glacier Changes Using ASTER and GIS Tools. - IEEE Transactions of Geoscience and Remote Sensing 42(10): 2177-2183.

[25] Krimmel, R.M., Meier, M.F. (1989): Glaciers and glaciology of Alaska. - American Geophysical Union. Washington D.C.

[26] Kuhn, H.W., Kuenne, R.E. (1962): An efficient algorithm for the numerical solution of the Generalized Weber Problem in spatial economics. - Journal of Regional Science 4(2): 21-33.

[27] Larsen, C.F., Motyka, R.J., Arendt, A.A., Echelmeyer, K.A., Geissler, P.E. (2007): Glacier changes in southeast Alaska and northwest British Columbia and contribution to sea level rise. - Journal of Geophysical Research 112(F01007): 1-11.

[28] Manley, W.F., Lestak, L.R., Tweedie, C.E., Maslanik, J.A. (2006): High-Resolution QuickBird Imagery and Related GIS Layers for Barrow, Alaska, USA. - Boulder Colorado USA: National Snow and Ice Data Center.

[29] Mayo, L.R., Zenone, C., Trabant, D.C. (1977): Reconnaissance hydrology of Portage Glacier basin. - Fairbanks: Department of the interior United States Geological Survey with Unites States Forest Service.

[30] Mefford, T., Dutton, E. (2003): Barrow Alaska climate monitoring and diagnostics: meteorology and radiation data. - Boulder Colorado USA: National Snow and Ice Data Center.

[31] Molnia, B.F. (2001). Glaciers of North America - Glaciers of Alaska. Satellite image atlas of glaciers of the world. - Printing by United States Geological Survey.

[32] Molnia, B.F. (2006): Late nineteenth to early twenty-first century behavior of Alaskan glaciers as indicators of changing regional climate. - Global and Planetary Change 56: 23-56.

[33] Molnia, B.F. (2008): Satellite image atlas of glaciers of the world, Alaska. - United States Geological Survey Professional Paper 1386-K. Government Printing Office Washington.

[34] Nistor, M.M. (2013): Geological and Geomorphological Features of Kenai and Chugach Mountains in Whittier Area, Alaska. - Studia UBB, Geographia 58: 27-34, Cluj-Napoca.

[35] Nistor, M.M., Petcu, I.M. (in press): The role of glaciers in the evolution of Prince William Sound landscape ecosystems. - Studia UBB, Ambientum, Cluj-Napoca.

[36] Oerlemans, J. (2005): Extracting a Climate Signal from 169 Glacier Records. - Science 308: 675-677.

[37] Oerlemans, J. (1994): Quantifying global warming from the retreat of glaciers. - Science 264: $243-245$. 
[38] Ommanney, C.S.L. (2002): Glaciers of the Canadian Rockies. United States Geological Survey Proffesional Paper 1386-J. - University of Michigan Libraries.

[39] O’Neel, S., Hood, E., Arendt, A., Sass, L. (2014): Assessing streamflow sensitivity to variations in glacier mass balance. - International Journal Devoted to the Description, Causes and Implications of Climatic Change (123: 329-341.

[40] Painter, T.H., Flanner, M.G., Kaser, G., Marzeion, B., VanCuren, R.A., Abdalati, W. (2013): End of the Little Ice Age in the Alps forced by industrial black carbon. Solomon, S. (editor). -Massachusetts Institute of Technology. Cambridge 110(38): 15216-15221.

[41] Paul, F., Kääb, A., Maisch, M., Kellenberger, T., Haeberli, W. (2002): The new remotesensing-derived Swiss glacier inventory: I. Methods. - International Glaciological Society 34(1): 355-361.

[42] Post, A. (1967): Effects of the March 1964 Alaska earthquake on glaciers. - United States Geological Survey Proffesional Paper 544-D. Reston.

[43] Qinghua, Y., Shichang, K., Feng, C., Jinghua, W. (2006): Monitoring glacier variations on Geladandong mountain, central Tibetan Plateau, from 1969 to 2002 using remotesensing and GIS technologies. - Journal of Glaciology 52(179): 537-545.

[44] Raup, B., Kääb, A., Kargel, J.S., Bishop, M.P., Hamilton, G., Lee, E., Paul, F., Rau, F., Soltesz, D., Khalsa, S.J.S., Beedle, M., Helm, C. (2007): Remote sensing and GIS technology in the Global Land Ice Measurements from Space (GLIMS) Project. Computers and Geosciences 33: 104-125.

[45] Sambah, A.B., Miura, F. (2014): Integration of Spatial Analysis for Tsunami Inundation and Impact Assessment. - Journal of Geographic Information System 6: 11-22.

[46] Sauber, J.M., Molnia, B.F. (2003): Glacier ice mass fluctuations and fault instability in tectonically active Southern Alaska. - Global and Planetary Change 42: 279-293.

[47] Shahgedanova, M., Stokes, C.R., Gurney, S.D., Popovnin, V. (2005): Interactions between mass balance, atmospheric circulation, and recent climate change on the Djankuat Glacier, Caucasus Mountains, Russia. - Journal of Geophysical Research 110(D16107): 1-12.

[48] Stavig, L., Collins, L., Hager, C., Herring, M., Brown, E., Locklar, E. (2005): The effects of climate change on Cordova, Alaska on the Prince William Sound. - Alaska Tsunami Papers. Publishing Web. URL: https://seagrant.uaf.edu/nosb/papers/2005/cordovanurds.html. Accesed on 23 April 2014

[49] United States Geological Survey. LandsatLook Images. URL: http://landsatlook.usgs.gov/. Accesed on 22 February 2014.

[50] Western Regional Climate Center. Monthly summary data lister (SOD-TD3200). Temperature 1985-2010, 509829 Whittier Alaska. URL: http://www.wrcc.dri.edu/cgibin/cliMAIN.pl?ak9829. Accessed on March 5, 2014.

[51] Willis, M.J., Melkonian A.K., Pritchard, M.E., Ramage, J.M. (2011): Ice loss rates at the Northern Patagonian Icefield derived using a decade of satellite remote sensing. - Remote Sensing of Environment 117: 184-198.

[52] Wirth, L., Heinrichs, T., Broderson, D. (2014): Alaska geospatial data resources, proceedings of the Alaska Arctic vegetation archive workshop. - CAFF Proceeding Series Report Nr. 11. Boulder Colorado, USA.

[53] Zhang, T., Heginbottom J.A., Barry, R.G., Brown, J. (2000): Further Statistics on the Distribution of Permafrost and Ground Ice in the Northern Hemisphere. - Polar Geography 24(2): 126-131. 